\title{
ҮНДЭСТЭН ДАМНАСАН ГЭМТ ХЭРЭГ БА МОНГОЛ УЛСЫН ҮНДЭСНИЙ АЮУЛГУЙ БАЙДЛЫН ТУЛГАМДСАН ЗАРИМ АСУУДАЛ
}

А.Батсайхан*

\section{Удиртгал}

Өнөөдөр илэрхий болсон бодит байдал нь улс үндэстний болон дэлхийн соёл иргэншлийн хувь заяанд нөлөөлж болохуйц уламжлалт бус аюул буй болж заналхийлэх болсон явдал мөн. Уламжлалт бус аюул гэдэгт хүний буруутай үйл ажиллагаа болон цаг уурын өөрчлөлттэй холбоотой байгаль-экологийн доройтол, байгалийн гамшиг, түүний давтамжийн хугацаа ойрхон болсон, нийтийг хамарсан уламжлалт бус шинэ өвчний цар тахал, олон улсын терроризм, хил дамнасан зохион байгуулалттай гэмт хэрэг тухайлбал, хар тамхи, мансууруулах бодис, зэвсгийн хууль бус наймаа, хүн худалдаалах, мөнгө угаах зэргийг хамруулан ойлгож байгаа билээ. Бид энд уламжлалт бус аюулын зарим хүрээ тухайлан бохир мөнгө угаах, хүний наймаа, хар тамхи, мансууруулах бодисын хууль бус худалдаа, хэрэглээний асуудлыг үндэсний аюулгүй байдалтай холбон товч хөндөхийг зорив.

Даяаршлын үеийн үндэсний хийгээд олон улсын харилцааны үндсэн шинжийг хураангуйлан дүгнэвэл: дэлхийн эдийн засаг даяаршиж, бие биенээсээ улам бүр харилцан хамааралтай болж, ямар ч хүчирхэг эдийн засагтай улс, гүрэн

өөрийнхөө хөгжил дэвшил, үндэсний аюулгүй байдлаа дангаараа хангаж, хөтлөн авч явах бололцоогүй болсон, дэлхий дахины худалдаа-эдийн засаг, зах зээлийн харилцаанд мэдээлэл, ажиллах хүч, бараа, бүтээгдэхүүн, мөнгө, санхүҮ, хөрөнгийн асар өргөн шилжилт хөдөлгөөн, бүтээгдэхүүн, үйлчилгээний хил хязгааргүй урсгал явагдаж, улс орнуудын харилцан хамаарал гүнзгийрч, түүнд суурилсан даяаршлын цоо шинэ нөхцөл байдал нэгт буй болов. Хөгжиж байгаа орнууд олон улсын банк, санхүүгийн байгууллага, их гүрнүүдийн тусламж, нөлөө ивээлд улам бүр дулдуйдах болсон нь тэдгээр орнуудын хөгжлийн асуудал, үндэсний аюулгүй байдал тэдгээрээс олон талаар хамаарах болж байгаа, дөрөвт, зарчмын цоо шинэ үүрэгтэй болсон мэдээлэл, харилцаа холбооны технологийн үсрэнгүй хөгжилтэй уялдан орон зай, цаг хугацаа, эдийн засгийн шинжлэх ухааны тухай хуучин ойлголт үндсээрээ шинэчлэгдсэн, ялангуяа кибер орон 
зайд үндэсний аюулгүй байдлыг хангах шаардлага цоо шинээр гарч ирэв. Үндэсний эдийн засаг дэлхийн зах зээлийн хуулиар зохицуулагдаж, үндэсний баялаг, түүхий эдийн нөөцөө захиран зарцуулах нь нэг улсын эрх мэдэл, хил хязгаараас шалтгаалахгүй, хүний эрх, үндсэн эрх чөлөө, ардчилалын асуудал нь дан гагц улс орны дотоод хэрэг биш, харин олон улсын шинжтэй бөгөөд олон улсын шийтгэлтэй болов. Байгаль-экологийн гамшиг, цаг уурын өөрчлөлт, олон улсын терроризм, уламжлалт бус шинэ өвчний тархалт, хил дамнасан зохион байгуулалттай гэмт хэрэг, салан тусгаарлах ажиллагаа, шашны харгис урсгалын нөлөө зэрэг уламжлалт бус аюул үндэсний болон глобаль улс төр- эдийн засагт ноцтой уршиг тарих болсон, долоод, шавхагдашгүй биш болох нь тодорхой болсон манай гаригийн нөөц баялаг, хүн амын өсөлт, хүнс тэжээлийн хомсдол, өлсгөлөн, ядуурал нь глобаль шинжтэй болсон, наймд, дэлхий нийтэд ардчилал хөгжиж байгаа боловч, сайн засаглал, тогтвортой хөгжил ихээхэн эмзэг, сул байгаа үндэсний аюулгүй байдлын тогтолцоонд ялангуй хүний аюулгүй байдалд улам бүр сөрөг нөлөө үзүҮлж буй зэрэг санал, дүгнэлтүүд юм.

Тиймээс дэлхийн хамтын нийгэмлэг, улс орнууд, тэдгээрийн харилцаа, хамтын ажиллагааны өмнө томоохон зорилт, сорилт тулгарч байгаа нь тодорхой байна.

Монгол Улсын гадаад орчин сүүлийн 20 гаруй жилийн өмнөхөөс үндсээрээ өөрчлөгдлөө. Монгол Улс хоёр том гүрний дунд оршдог, далайд гарцгүй, дэлхийн зах зээлээс алслагдмал, буурай хөгжилтэй орон байсан бол эдүгээ дэлхийн хамгийн хурдан хөгжиж буй бүс нутагт орших болж, эрдэс баялаг, түүхий эд, эрчим хүчний үлэмж нөөцтэй нь тодорхой болсон явдал олон улсын анхаарал, их гүрнүүд, үндэстэн дамнасан бизнесийн бүлэглэлүүдийн геополитик, геоэдийн засгийн сонирхлыг татах болсон нь шинэ боломж, түүнчлэн шинэ эрсдлийг дагуулах болов. Нэг талаас даяаршсан шинэ ертөнц буй болж, мэдээлэл, харилцаа холбооны технологийн үсрэнгүй хөгжлөөс үҮдэн мэдээллийн ертөнцөд томоохон өөрчлөлтүүд гарч, мэдээлэл харилцааны цоо шинэ орчин буй болсон явдал юм. Нөгөө талаас мэдээлэл, харилцаа холбоо нь өөрөө үндэсний нөөц баялаг, улс орны хөгжил дэвшилд нөлөөлөх чухал хүчин зүйл болов.

Монгол Улсын Мянганы хөгжлийн зорилтод суурилсан үндэсний хөгжлийн цогц бодлого, Үндэсний аюулгүй байдлын шинэчилсэн үзэл баримтлал, Гадаад бодлогын шинэчилсэн үзэл баримтлалыг хэрэгжүүлэх хүрээнд Монгол Улсын төр, нийгэм-эдийн засаг, хувь хүний аюулгүй байдал, гадаад орчин дэх аюулгүй орчныг буй болгох, хангах шаардлага зүй ёсоор урган гарч байна. Дэлхий дахины худалдаа-эдийн засаг, зах зээлийн харилцаанд мэдээлэл, ажиллах хүч, бараа бүтээгдэхүүн, мөнгө, санхүү хөрөнгийн асар өргөн шилжилт хөдөлгөөн, бүтээгдэхүүн, үйлчилгээний хил хязгааргүй урсгал явагдаж, 
улс орнуудын харилцан хамаарал гүнзгийрч, түүнд суурилсан даяаршлын цоо шинэ нөхцөл байдал буй болов. Түүнчлэн энэ чиглэлд эрхзүйн орчныг боловсронгуй болгох асуудал урган гарч байна.

Монгол улсын зэвсэгт хүчин Энхийг сахиулах болон Олон улсын цэргийн ажиллагааны хүрээнд Ирак, Афганистан, Сьерра Леон, Чад, Судан улсад үүрэг гүйцэтгэж байгаа нөхцөлд олон улсын чанартай уламжлалт бус аюулаас урьдчилан сэргийлэх, юуны өмнө олон улсын терроризм, салан тусгаарлах үйл ажиллагаа, шашны харгис урсгалуудын нөлөө нэвтрэх магадлал маш өндөр байна. Хоёр их гүрний хооронд оршиж байгаа Монгол Улсад хууль бусаар мансууруулах бодис, хар тамхи тараах, хэрэглэх, тээвэрлэх, дамжин өнгөрүүлэх, галт зэвсэг болон хүн худалдаалах, мөнгө угаах зэрэг олон улсын чанартай үндэстэн дамнасан зохион байгуулалттай гэмт хэрэг гарах боломж мөн өндөр байна. Төв Азийн бүс нутагт террорист байгууллагад бүртгэгдсэн бүлэглэлүүдийн үйл ажиллагаа идэвхжиж, элдэв халдлага, дайралтууд өргөжин, үйл ажиллагаагаа тэлэх хандлагатай байгаа нь Монгол Улсын өргөн уудам газар нутаг, түүнчлэн эрчимтэй хөгжлийн замд эргэлтгүй гарч ирээд буй нөхцөл байдлыг ашиглан нэвтрэн суурьших магадлалтай. Хүний буруутай үйл ажиллагаа болон цаг уурын өөрчлөлт, улс төрийн намуудын сонгуулийн амлалтууд болон ард иргэдийн ядуурлын ялгаа, Монгол Улсын хүрээлэн буй орчин эрс бохирдож, онгон байгалийн тэнцвэрт байдал алдагдаж, хүн, амьтны гаралтай гоц халдварт өвчний гарах давтамжийн хугацаа богиносож ихээхэн дэлгэрэх болов.

“Монгол Улсын Мянганы хөгжлийн зорилтод суурилсан үндэсний хөгжлийн цогц бодлого”-д “олон улсын терроризм, салан тусгаарлах үйл ажиллагаа, шашны харгис урсгалуудын нөлөө нэвтрэх, хар тамхи тараах, дамжуулан өнгөрүүлэх, хууль бусаар зэвсэг болон хүн худалдаалах зэрэг олон улсын чанартай гэмт хэрэгтэй тэмцэхэд гадаад орнуудын ижил төрлийн байгууллагатай идэвхитэй хамтран ажиллах”, “Монгол Улсын Үндэсний аюулгүй байдлын шинэчилсэн үзэл баримтлал”-ийн 3.4,4-д: “Иргэдийг үндэстэн дамнасан гэмт хэргээс хамгаалах хэсэгт: “Иргэдийн терроризм, үндэстэн дамнасан зохион байгуулалттай гэмт хэрэг, хүчирхийллээс хамгаалагдах нөхцлийг сайжруулна”, “Хүүхэд, эмэгтэйчүүд, иргэдийг хүн худалдаалах гэмт хэрэгт өртөхөөс урьдчилан сэргийлэх, таслан зогсоохтой холбогдсон эрх зүйн орчныг боловсронгуй болгож энэ чиглэлд бэхжүүлнэ”, “Мансууруулах, сэтгэцэд нөлөөлөх бодисын эргэлтэд хяналт тавих, хууль бус хэрэглээтэй тэмцэх үндэсний чадавхийг бэхжүүлнэ” гэж заасан байна. Энд анхаарах нэг асуудал нь бохир мөнгө угаах асуудлын тухай огт дурьдалгүй орхигдуулсан явдал болно. 


\section{Мөнгө угаax (money laundering) гэмт хэрэг, түүний илрэл}

Хууль бус аргаар олсон мөнгө, хөрөнгө угаах явдал нь янз бүрийп арга хэрэгслээр хийгдэх санхүүгийн олон төрлийн ярвигтай процессээр илрдэг. Өнөөгийн байдлаар мөнгө угаах маш олон төрөл, арга илэрсэн байна. Үүнийг хууль хамгаалах байгууллагынхан мэдсэн ч хууль бус мөнгөний эх сурвалж буюу анхны эх үүсвэр нь чухам хаанаас ямар аргаар гарсныг илрүүлж чадддагүй учраас таслан зогсооход маш хүндрэлтэй байдаг ажээ. Мөнгө угаах хэмээх нэр томъёо 1930-аад оны үед анх Чикагогийн Сицили гаралтай мафийи толгойлогч Аль Капоне өөрийн мэдэлд байсан хими цэвэрлэгээний газруудьн санхүүгийн тайланд өөрсдийн орлогоо хэд дахин ихэсгэж бичээд түүн дотроо бохир мөнгөө шингээж хууль ёсны мэт харагдуулдаг байснаас ҮҮдэлтэй ажээ.* 1999 оны 5 дугаар сард батлагдсаи ОХУ-ын Мөнгө угаах гэмт хэргийн эсрэг тэмцэх тухай хуулийи 3-р зүйлийн 2 дахь хэсэгт заахдаа: "... нийгэмд аюултай хууль бус ажиллагааны үндсэн дээр бий болсон мөнгө болон бусад эд хөрөнгийг хууль ёсны мэт болгон харагдуулах, түүнийг эзэмших, ашиглах, эргэлтэнд оруулах явдал**" хэмээн тодорхойлсон байна.

Мөнгө угаах гэмт хэргийн хэлбэр, түүний үе шат: Мөнгө угаах аргын хэд хэдэн төрөл байдаг байна. Үүнд:

Нэгд: Хоёр шатлал бүхий загвар;

Хоёрт: Гурван шатлал бүхий загвар;

Гуравт: Дөрвөн шатлал бүхий загвар;

Эдгээрээс хамгийн өргөн тархсан арга бол гурван шатлал бүхий загвар юм. Энэ арга нь Нэгд , Р1acement (солих хутгах) буюу бохир бөгөөд бэлэн мөнгийг санхүүгийн өөр хэрэгслээр солих буюу биежүүлэх; хоёрт, Layering ( шат давхарга болгох) буюу мөнгө угаагч болон бохир эх сурвалжийг тусгаарлах; гуравт, Integration буюу зарим тохиолдолд зах зээлд буцаан оруулах гэх нэршил бүхий үе шаттай байдаг ажээ. Тухайлбал:

Placement буюу эхний үе шатанд хууль бусаар хар тамхи, мансууруулах бодис, зэвсгийн наймаа, садар самуун, порнограф, хүний наймаа, далд эдийн засгийн орлого, татвараас займчуулсан мөнгө, хөрөнгө, хуурамч мөнгийг жинхэнэ болгож солих зэрэг үйл ажиллагаанаас олсон их ХЭМЖЭЭНИЙ "бохир" бэлэн мөнгийг санхүүгийн төлбөрийи харьцангүй биет, илүү том хэлбэрт шилжүүлэн үнэт цаас, чек, валют, бараагаар солих 
үйл ажиллагаа явагддаг. Түүнээс гадна угаасан мөнгөний тодорхой хэсгийг парламент, ерөнхийлөгчийн сонгууль, улс төрийн нам, эвсэл, хөдөлгөөн, захиалгат аллага, олон улсын терроризмийг санхүүжүүлэх, авилга хээл хахууль зэрэгт ашигладаг байна.

Layering буюу хоёр дахь үе шатны зорилго нь мөнгө угаагч болон бохир мөнгийг хооронд нь салгах, өөрөөр хэлбэл мөнгө угаагч хууль бус үйл ажиллагаанаас олсон мөнгө, эд хөрөнгөө юуны өмнө өөрөөсөө холдуулах буюу мөнгө угаагч ба бохир мөнгө хэмээх ухагдахуунуудын хоорондын шалтаант холбоог үгүй хийх явдал юм. Энэ үед аудитийи болон бусад хяналт шалгалтаас зайлсхийхийи тулд санхүүгийн ямар нэгэн маш том, ээдрээтэй хэлцэл хийж банкны харилцах цахим дансыг ашиглан их хэмжээний мөнгөн гуйвуулга хийдэг ажээ. Өөрөөр хэлбэл нэг бүс нутгаас үйл ажиллагааны үл хамаарал бүхий өөр бүс рүү банкны дансаар бохир мөнгөө шилжүүлдэг. Судлаачдын тооцоолсноор дэлхий дээр өдөр бүр банкны цахим дансаар 500.000 гаруй удаагийн мөнгөн гуйвуулга хийгддэг ба энэ нь дунджаар 1 их наяд ам. долларгай тэнцдэг байна. ОУВС, Дэлхийн банк болон АНУ-ын Төрийн департментын гаргасан тооцоогоор дэлхий дээр угаагдаж буй мөнгөний хэмжээ дэлхийн улс орнуудын ДНБ-ий 2-4 хувьтэй тэнцдэг, мөнгөн дүн нь 590 тэрбумаас 1 их хаяд 500 тэрбум ам. долларт хүрсэн гэсэн тооцоог гаргажээ. ЭнэхүҮ 590 тэрбум ам.доллар гэдэг нь Испанийн ДНБ-ий хэмжээтэй тэнцэж байна гэсэн үг юм.***

ЭнэхүҮ данс, гуйвуулга болгоны талаар хангалттай баримт мэдээлэл байдаггүй учир гэмт хэрэгтнүүдэд бохир мөнгөө угаах аятайхан боломж бүрддэг ажээ*. Угаах шатанд олон төрлиии санхүүгийи байгууллагуудыг ашигладаг бөгөөд үүнд: нэгд: санхүүгийи уламжлалт байгууллагыг ашиглах, хоёрт: санхүүгийн уламжлалт бус байгууллагуудыг ашиглах, гуравт, санхүүгайн бусад байгууллагыг ашиглах гэх мэт аргууд хамаарна.

Санхүүгийн уламжлалт байгууллага гэдэгт санхүүгийн үйл ажиллагааг лиценз болон зөвшөөрлийн үндсэн дээр эрхэлдэг байгууллагуудыг хэлнэ. Үүнд: Банк, банк бус санхүүгийн байгуулага, тэтгэврийн сан, даатгалын байгууллага гэх мэт. Харин уламжлалт бус гэдэгт валютын шуудан, илгээмжийн үйлчилгээний байгууллагууд ордог. Санхүүгийн бус гэдэгт чиг үүргийн хувьд санхүүгийн бус үйл ажиллагаа эрхэлж буй аль ч байгууллага, тухайлбал: казино, дэлгүүр, ломбард буюу барьцаалан зээлдүүлэх газар, баар, ресторан, валют солих цэг гэх мэт орж байна.

СүҮлийи үеийн мэдээнээс үзвэл ОХУ-д мөнгө угаах чиглэлээр байгуулагдсан 3000 гаруй байгууллага байдаг гэх бөгөөд үүний 1500 гаруй нь хувийн банк ажээ. Мөн 
дээрх хэлбэрээр байгуулагдаагүй ч мөнгө угаах, дамжуулахад тусалж, тэдний хяналтанд ажилладаг төрийн болон төрийн бус 40000 гаруй байгууллага бий гэсэн мэдээ байна. 2003 онд их хэмжээний мөнгө угаасан явдалд Их Британийн нэртэй банк болох Int'l Bank of Credit \& Commerce холбогдож багагүй шуугиан тарьсан билээ**.

ХБНГУ-ын судлаач П.Бернаскон мөнгө угаах гэмт хэрэгт холбоотой улс орныг "үндсэн улс", "туслах улс" гэж хоёр ангилсан байна. "Үндсэн" гэдэг нь үндсэн гэмт ажиллагаа явагдсан улс, харин "туслах" гэдэг нь мөнгө угаах зорилгоор шилжүүлэгдсэн тэр улсыг хэлдэг*** ажээ. 2000-иад оны дундуур ОХУ-ын Юкос комнанитай холбоотой гэх их хэмжээний мөнгө угаасан хэрэг Израиль, Испанид илэрсэн билээ.

Санхүүгийн байгууллагуудаар дамжуулаи бохир мөнгөө өөр улсад үйл ажиллагаа эрхэлдэг өөрийн аль нэг байгууллагад гуйвуулахдаа хэд, хэдэн банк юм уу, нэг банкны хэд хэдэн данс ашиглаж мөнгөө хэд хэд хуваан шилжүүлдэг байна. Тухайлбал хүлээн авч буй нөгөө улсад нь мөн хэд хэдэн данснаас хүлээн авч байх жишээтэй. Учир нь АНУ, ОХУ, Австрали, ХБНГУ зэрэг улсад банкаар гуйвуулж буй мөнгөний болон хуулийн этгээдүүдийн хооронд байгуулж буй гэрээ хэлцлийн мөнгөний хэмжээг хуулиар тогтоосон тодорхой хэмжээнд хүрсэн тохиолдолд төрийн зохих байгууллагаас хяналт шалгалт хийдэг. Тухайлбал энэ хэмжээг АНУ-д 10000 доллараар тотоосон бол, ОХУ-д хөдөлмөрийн хөлсний доод хэмжээг иргэд хооронд 2000 дахин, хуулийн этгээд хооронд 20000 дахин ихэсгэсэнтэй адил гэх зэргээр заажээ.

Integration буюу зах зээлд буцаан оруулах үе шат нь мөнгө угаах гэмт хэргийн сүүлийн шат бөгөөд бохир мөнгө нь эдийн засгийн чөлөөт эргэлтэнд орсноор "бохир" хэмээх тодотголоос бүрэн салдаг ажээ. Иймээс өмнөх хоёр шатанд тухайн гэмт үйл ажиллагааг илрүүлж чадаагүй бол энэ шатанд бохир мөнгийг цэвэр мөнгөнөөс салгахад маш төвөгтэй болдог. Зарим тохиолдолд хоёрдахь шатыг 2 удаа давтах явдал ч бий. Энэ нь мөнгө угаах гэмт хэргийг илрүүлэх ажиллагааг улам хүндрүүлдэг ба хэд хэдэн улсыг дамжиж байж туслах улсад хүрдэг ажээ. Эндээс "дамжлага улс" гэсэн нэг ойлголт гарч ирж байгаа юм. Тухайн гэмт үйл ажиллагааны хэлбэр нь тухайн улсад мөнгө угаах гэмт хэргийн эсрэг хууль гарсан эсэх, санхүүгийн хяналт шалгалтын байдал, хууль хамгаалах байгууллагын үйл ажиллагааны чанар зэргээс шалтгаалан өөрчлөгддөг ажээ.

Мөнгө угаах гэмт хэргийг гадаад орнуудад маш ноцтой гэмт хэрэгт тооцдог. Учир нь мөнге угаах гэмт хэрэгт бусад гэмт хэрэг шиг бодитой хохирогч, материаллаг хохирол зэрэг гарт баригдаж нүдэнд үзэгдэх зүйл байдаггүй. Энэхүү гэмт хэргийн нэг аюултай тал нь тухайн гэмт бүлэглэл хууль бус орлогоороо улсын эдийи засаг, улс 
төрийн үндсийг нөхцөлдүүлж, нийгэмд байр сууриа бэхжүүлэхийг эрмэлздэгээр тодорхойлогддог. Мөн тухайи улсад буй мөнгөний эргэлтийг сааруулж, их хэмжээний мөнгө, үнэт цаасыг гадаадад гаргадаг. Жишээ нь: 2003 онд Америкийн судлаачид "ОХУaас АНУ руу мөнгө угаах гэмт хэргийн үндсэн дээр долоо хоногт дунджаар 800 саяас нэг тэрбум доллар шилжин орж байна" гэсэн судалгаа гаргасан байна. Иймээс энэ байдал ОХУ-ын эдийн засагт томоохон сөрөг нөлөө үзүүлж байгаа юм.

Нөгөө талд Монгол Улс мөнгө угаах дамжлага улс болсон нь ч тодорхой болж байна. Хадгаламж авдаггүй, зээл олгодоггүй хэрнээ үйл ажиллагаа явуулж буй гадны хөрөнгө оруулалттай гэх зарим банк ихээхэн анхаарал татаж байна. Монгол Улсад мөнгө угаах гэмт хэргийн талаарх ойлголт нэг мөр болоогүй, түүнтэй тэмцэх, илрүүлэх арга боловсронгуй болоогүй байгаа нь энэ гэмт хэрэг ер байхгүй, гараагүй байгаа гэж ойлгох үндсийг бүрдүүлж байгаа юм. 1990-ээд оны сүүлээр Орос-Монголын хамтарсан "Эрдэнэт" үйлдвэрт Төрийн хянан шалгах хорооноос хийсэн шалгалтаар тус үйлдвэрт мөнгө угаах шинж тэмдэг илэрсэн ба мөн үйлдвэрийи өмнөх удирдлагатай холбоотой зэрэг асуудлын улмаас 7.5 тэрбум төгрөгийи зөрчил гарсныг тогтоож байжээ. Үүнийг ТХШХ мэдээлж, дээрх асуудлыг УИХ-аар хэлэлцүҮлэхийи өмнө Үндэсний аюулгүй байдлын Зөвлөлөөр хэлэлцүүлнэ гэж байсан нь "Эрдэнэт" үйлдвэрт мөнгө угаах гэмт хэргийн шинж тэмдэг илэрсэн байж болзошгүй гэх таамаглалын төрүүлж байсан юм.

Мөн үед Засгийн газрын 80 дугаар тогтоолоор төрийн өмчийн" Сэргээн босголт" банкыг хувийн өмчийн "Голомт" банктай нэгтгээд, дараа нь дампууруулж, дундаас нь их хэмжээний мөнгө завшсан гэх сэжиг гарсан нь буй. Мөн Транс банкны эргэн тойронд болж буй шуугиан ч анхаарал татаж байна.

Гадаад улс орнуудад төрийн өндөр албан тушаалтнууд эрх мэдлээ урвуулан ашиглаж мөнгө угаадаг явдал түгээмэл байдаг. Үүнд 2001 онд Ююславын Ерөнхийлөгч асан С.Мелошевич, ОХУ-ыи Ерөнхийлөгч Б.Елыцин нар ч сэжиглэгдэж байсан юм. Тэр ч байтугай мөнгө угаах гэмт хэргийг олон улсын терроризмтай холбон ярьж, түүнийг санхүүжүүлэх гол эх үүсвэр болж байна гэж үздэг. Жишээ нь, саяхныг болтол Афганистанд ноёрхлоо тогтоож, оршин тогтнож байсан Талибаны дэглэм, Аль Кайдагийн террорист байгууллагын сүлжээ өөрийн санхүүгийнхээ нэлээд хэсгийг тухайн бүс нутаг дахь хар тамхины тариалан, түүний худалдаанаас олдог байсан нь тодорхой болсон билээ. Энд тариалж боловсруулсан хар тамхийг ОХУ болон Европын орнууд, Дорно зүгт Хятад гэх мэт орнуудад нийлүүлдэг бүхэл бүтэн сүлжээ байсан байна. Зөвхөн энэ төрлийн худалдаанаас жилд дунджаар 2 тэрбум шахам (албан бус) ам. доллар олдог гэсэн тооцоо гарчээ. 
Ер нь олон улсын хэмжээнд хар тамхи үйлдвэрлэх үндсэн 3 төв байдаг байна. Үүнд:

1. "Алтан гурвалжин" буюу Лаос, Бирм, Тайландын хилийн зааг нутаг;

2. "Алтан шинэ саран " буюу Афганистаны нутаг дэвсгэр;

3. "Кокайны баянбулаг" буюу Андын нуруу, Колумбын нутаг зэрэг болно.

Сүүлийн үед Монгол Улсад гадаадын олон байгууллага / хувийн банк, цэнгээний газар/ үйл ажиллагаагаа явуулах болсон нь анхаарал татаж байгаа юм. Жишээ нь: Чингис хаан банк, Кредит банк зэрэг нь хадгаламж авдаггүй, зээл олгодоггүй мөртлөө Монгол Улсад үйл ажиллагаа явуулсаар байна. Үүний хажуугаар томоохон хувьчлал, их хэмжээний хөрөнгө оруулалтыг мөнгө угаах үйлдлүүд ,авилга, хээл хахууль ямагт дагалдаж байдаг нь нууц биш юм. Өөр нэг зүйл гэвэл Монгол Улс дээр хэлсэнчлэн үндсэн болон туслах улсын хоорондох / Орос-Хятад / дамжлагын шинжтэй гүүр улс болчихоод байгаа юм биш биз гэсэн таамаглал байдаг.

Эдгээр нь цаашлаад далд эдийн засгийн хүчин зүйл болж байна. Үүнтэй холбогдуулаад Монгол Улсын далд эдийн засгийн талаар товч хэлэхэд:

1. Манай орны хувьд далд эдийн засгийн хэмжээг бүрэн судалж албан ёсоор тогтоогоогүй. Харин 1997 онд Дэлхийн банкнаас Улаанбаатар хотын хэмжээнд албан бус сектор дахь хэмжээг судалжээ.

2. 1999 онд Монгол Улсын Үндэсний Статистикийи Газар, Засгийн Газрыи Хэрэг эрхлэх газрын дэргэдэх "Эдийн засгийи бодлого дэмжих" төсөлтэй хамтран албан бус секторыи судалгааг 6 аймаг, Улаанбаатар хотын 14 салбарт хийж хэмжээг нь 117 тэрбум төгрөг гэж тогтоосон нь ДНБ-ий 13.3 хувь болж байв. Энэ нь далд эдийн засгийн нэг томоохон хэсэг ГЭДЭГ НЬ ойлгомжтой. Үүний 62 хувь нь жижиглэн худалдаа, 23.3 хувь нь тээврийи үйлчилгээний салбарынх байжээ.

Олон улсад мөнгө угаах гэмт хэрэгтэй тэмцэх үндсэн гурван арга байдаг. Үүнд:

1. Эрүүгийн хүрээн дэх эрхзүйн тэмцэл;

2. Санхүүгийн хяналт;

3. Олон улсын хамтын ажиллагаа зэрэг болно.

Эрүүгийн эрхзүйн тэмцэл гэдэг нь тухайн мөнгө угаах гэмт хэргийин бохир мөнгөнийх нь эх сурвалжийг олж илрүүлэх, түүнийг таслан зогсоох, угаагдсан мөнгийг цааш нь зах зээлийн эргэлтэнд оруулах буюу эргээгээд хууль бус үйл ажиллагаанд ашиглахын эсрэг тэмцэх явдал юм. Энэхүү ажиллагаанд эрүүгийн бусад гэмт хэрэгтэй тэмцэхэд ашигладаг аргуудыг голчлон хэрэглэдэг. 
Санхүүгийн хяналт: Ихэнх улс орнууд тухайн гэмт бүлэглүүдийг бохир аргаар олсон мөнгөө санхүүгийн байгууллагуудад шилжүүлэхэд хяналт тавьж илрүүлэхийг гол зорилтоо болгодог. Тиймгээс санхүүгийн уламжлалт болон уламжлалт бус байгууллагууд дээр гол анхаарлаа төвлөрүүлдэг

Өнөө үед санхүүгийн хяналтын дор дурдсан гурван хэлбэр байдаг. Үүнд:

1. Хуулиар тогтоосон тодорхой хэмжээнд хүрсэн их хэмжээний мөнгөөр хийгдэж буй хэлцлүүдийн талаар төрийн зохих байгууллагад мэдээлэх; Энэ нь анх АНУ, Австралид дэлгэрсэн ажээ. АНУ-д 10000 доллараас дээш хэмээтэй хэлцэл хийсэн, банкны дансаар мөнгө гуйвуулсан тохиолдолд төрийн зохих байгууллагад хяналт, шалгалт хийдэг байна.

2. Банк, санхүүгийн байгууллага нь аливаа нэг сэжиг бүхий хэлцлийг төрийн зохих байгууллагуудад мэдээлж байх; Энэхүү аргын гол дутагдалтай тал нь чухам ямар хэлцлийг "сэжиг бүхий" гэж үзэх вэ гэдэг асуудалтай тулгардаг явдал юм.

3. Их хэмжээний бэлэн мөнгөний оролцоотой аливаа нэг хэлцэл хийхэд заавал төрийн байгууллагын тусгайлан томилсон төлөөлөл байлцах явдал юм. Энэ нь Италид өргөн хэрэглэгдэж буй арга юм. Их хэмжээний мөнгөтэй холбоотой ямар ч хэлцэлд төрийн зохих байгууллагаас томилсон хүн хяналтын чиг үүрэгтэй оролцдог байна. Гэвч энэхүү аргыг ихэнх улс орон эсэргүүцэж байгаа бөгөөд учир нь байгууллага, хувь хүний нууцад халдаж буй явдал гэж үздэг байна.

1989 оны Их долоогийн уулзалтаас гаргасан “Мөнгө угаахын эсрэг санхүүгийн аргаар тэмцэх олон улсын байгууллагын 40 зөвлөмж” бохир /хууль бусаар олж авсан/ мөнгө цэвэршүүлэхийг гэмт хэрэгт тооцох, түүний хууль бус эх сурвалжийг илрүүлэх, хураамж авах зэрэг журам тогтоосон 1990 оны “Гэмт үйл ажиллагаанаас олсон орлогыг угаахыг илрүүлэх, хураах тухай” Страсбургийн конвенци, 1994 оны НҮБ-ын Ерөнхий Ассамлейн “Гэмт үйл ажиллагаанаас олсон орлогыг ашиглах, мөнгө угааж цэвэршүүлэхээс урьдчлан сэргийлэх, түүнтэй тэмцэх тухай” тогтоол зэрэг баримт бичгүүд үйлчлэх болсон нь мөнгө угаах гэмт хэргийн өнөөгийн шинж төрхийг тодорхойлж байна.

1997 онд Тайландын Бангкок хотноо болсон “Мөнгө угаах үзэгдлийн талаар АзиНомхон далайн орнуудын симпоузм"-ын үеэр мөнгө угаахтай тэмцэх”Ази-Номхон далайн групп хэмээх байгууллага байгуулагдсан байна. Дурдсан байгууллагад 26 гишүүн, 13 ажиглагч орон багтаж байгаа бөгөөд Монгол Улс ажиглагчийн статустай юм.

Энэ бүгдийг үндэслэвэл Монгол Улсад мөнгө угаах гэмт хэрэг биеллээ олж эхэлж байна гэж үзэж болох талтай. Шинэчилсэн Эрүүгийн хуулийн 163-р зүйлд /хууль бусаар 
олж авсан хөрөнгө мөнгө ашиглах/ энэ талаар зохицуулалт оруулсан боловч ерөнхийдөө хангалтгүй байна.

1. Мөнгө угаах гэмт хэрэгтэй тэмцэх аргыг боловсронгуй болгох асуудлыг хөндөхийн өмнө энэхүү гэмт хэрэг Монгол Улсад ямар бодит хор хохирол учруулж болох вэ? гэдгийг авч үзэх нь зүйтэй.

2. Энэхүу гэмт хэргээс нийгэмд учруулах хор хохирол нь:

1. Монгол Улсад хууль бусаар хар тамхи, мансууруулах бодис, зэвсэг, хүн наймаалах, садар самуун, порнографи зэрэг мөн далд эдийн засаг өргөжин тэлж аюул учруулах;

2. Гурван сая хүрэхгүй цөөн хүн амтай улс оронд дээрх хууль бус ажиллагаанууд дэндүҮ их сөрөг нөлөөтэй бөгөөд хүн ам, эдийн засгийн аюулгүй байдалд нэн их хохирол учруулж болох;

3. ЭнэхүҮ гэмт ажиллагааг хэрэгжүүлэгч бүлэглэлүүд Монгол Улсын нийгэм, эдийн засаг, улс төрд байр сууриа бэхжүүлэх аюултай;

4. Монгол Улсын нийт мөнгөний эргэлт саарч, мөнгөн хөрөнгийн үлэмж хэсэг гадаад орнуудад шилжих, байрших магадлал өндөр;

5. Энэ гэмт хэрэг нь банк, санхүү, хууль хамгаалах байгууллагуудын үйл ажиллагааны чанараас шалтгаалдаг тул банкны үйл ажиллагаа цалгардах, түүний улмаас төрийн эрх бүхий албан тушаалтнууд эрх мэдлээ ашиглан авига авах, улсын мөнгийг угаах аюултай. Иймээс:

1. Мөнгө угаах гэмт хэрэгт хууль хамгаaлах байгууллага болон банк, санхүүгийн байгууллагуудын зүгээс тавих хяналтыг бий болгох зорилгоор Эрүүгийн цагдаа, Тагнуулын байгууллагын тухай зэрэг хуулиудад уг гэмт хэрэгт тавих хяналтын чиг Үүргийг тусгаж оруулах;

2. Төв банк болон бусад арилжааны банкуудад тавих хяналтьг сайжруулах, мөнгө угаах гэмт хэрэг гарахаас урьдчилан сэргийлэх үүднээс банкуудад "Мөнгө угаах гэмт хэрэгтэй тэмцэх алба" байгуулах; /Энэ алба нь банкаар дамжуулан хийгдэж буй аливаа нэгэн хэлцэлд хяналт тавина;

3. Дээрх хэлцлүүдийн талаарх мэдээллийг банк, санхүүгийн байгууллагын ажилтнууд төрийн зохих эрх бүхий байгууллагад мэдээлээгүй тохиолдолд эрүүгийн хуулиар хариуцлага хүлээлгэдэг байх;

4. ФАТФ/Financial Acion Tаsк on Money Laundering буюу Мөнгө угаaх гэмт хэрэгтэй тэмцэх байгууллага 1989 онд байгуулагдсан/-тай цаашид хамтран ажиллах замаар олон улсын хэмжээнд тэмцэх; 
5. "Мансууруулах бодис болон сэтгэцийн эмгэг бодисыи хууль бус эргэлтийн эсрэг тэмцэх тухай " 1988 оны Венийн Конвенцид нэгдэн орох;

6. Бусад улс орны нэгэн адил мөнгө угаах гэмт хэрэгтэй тэмцэх тухай хууль батлан гаргаж, улмаар гэмт хэрэгтэй хийх тэмцлийн эрхзүйн орчин, үндсийг нь буй болгох; Үүнд:

нэгд, гуйвуулах мөнгөний тодорхой хэмжээг заах /Монгол Улсад 10 сая төгрөгөөс дээш байвал зохистой/;

хоёрт, сэжиг бүхий /ямар нэг эрхзүйн үндэслэлгүй буюу хэлбэрийи төдий хэлцэл/ тохиолдолд хяналт шалгалт хийх чиг үүртэй байх /энэ алба ОХУ-д "Подразделение финансовой разведки" хэмээн нэрлэгддэг/; шаардлагатай.

Дээрх арга хэмжээнүүд болон бусад холбогдох үйл ажиллагааг даруй хийж, урьдчилан сэргийлэх арга хэмжээг авахгүй бол Монгол Улсыг хөрш болон бусад гүрнүүд, үндэстэн дамнасан корпораци, бүлэглэлүүд геополитик, геоэдийн засаг, стратегийн байршлалд анхаарлаа илтэд хандуулж буй үед, хүн ам багатай, нутаг дэвсгэр уудам улсын эдийн засаг тодорхой хэмжээгээр гадаад улсын хараат болох ба өргөн утгаараа Монгол Улсын үндэсний аюулгүй байдалд ноцтой хохирол учруулах болно.

\section{Хүн худалдаалах (human trafficking) гэмт хэрэг, түүний илрэл}

Өнөөдөр дэлхийн улс орнуудын өмнө тулгарч буй сэтгэл түгшээсэн нэг үзэгдэл бол улс дамнасан зохион байгуулалтай гэмт хэргийн нэг төрөл болох иргэдийн эрх, эрх чөлөө, хувь хүний аюулгүй байдалд ноцтой халдах, зөрчих явдлаар илэрдэг хүн худалдаалах явдал хүрээгээ тэлсээр байгаа нь дэлхийн улс орнууд, тэдгээрийн төр, засгийн анхаарлын төвд зүй ёсоор орох болов. НҮБ-ын мэдээгээр жилд дунджаар 1 сая орчим хүүхэд, эмэгтэйчүүд болон эрчүүд бэлгийн болон бусад төрлийн мөлжлөг, хүний эд эрхтэн наймаалах зорилгоор худалдаалагдаж байгаа ажээ. Олон улсын шинжээчдийн дүгнэлтээр зохион байгуулалттай гэмт бүлэглэлүүдийн хүн худалдаалах гэмт хэргээс олж байгаа жилийн орлого 9.5 тэрбум ам. долларт хүрч байна.

НҮБ-ын Хүүхдийн сангийн илтгэлд дурдсанаас үзэхэд хэрэв олон улсын хүчин чармайлтаар дорвитой арга хэмжээ авч хэрэгжүүлж чадахгүй ахуйл 2011 оны эцэс гэхэд хүн худалдаалахаас олох орлого хар тамхи, мансууруулах бодисын наймаанаас олох орлоготой эн зэрэгцэх ажээ. Түүнээс гадна хүний наймаанаас олсон орлого нь олон улсын терроризмийг санхүүжүүлэхэд зарцуулагдах бүрэн үндэслэлтэй гэсэн болгоомжлолыг төрүүлж байгаа юм. Үүнээс үзвэл, хүн худалдаалах гэмт хэрэг нь бусад төрлийн гэмт хэрэгүүдийг, мөн бусад ноцтой үзэгдлүүдийг байнга дагуулж байгаa ажээ. 
Хүн худалдаалах гэмт хэрэгт ихэвчлэн хүүхэд, эмэгтэйчүүд өртөж байна. Ийм хэргийн нэг хэлбэр болох боолын худалдаанд эрчүүд ч бас нэрвэгдэж байгаа юм. АНУ ын ТТГ-ын мэдээгээр Европт нийт худалдаалагдсан хүмүүсийн 2 хувийг эрчүүд эзэлдэг, хүн худалдаалах гэмт хэргийн хохирогчдын ойролцоогоор 80-90 хувь нь бэлгийн мөлжлөгийн золиос болж байна.

Хүн худалдаалах нь Монгол Улсад харьцангуй шинэ үзэгдэл боловч хүний худалдаа үйлдэгдэх нөхцөл нь хэдийнээ бүрдсэн байна. Нийгэм-эдийн засгийн тогтолцоо бүхэлдээ эрс өөрчлөгдөн, зах зээлийн харилцаанд шилжих болсонтой холбоотой ядуурал, ажилгүйдэл зэрэг шинжтэй сөрөг үзэгдэл төдийгүй иргэд гадаадад зорчин явах эрх чөлөөтэй болсон зэрэг хүний эрхийн хүрээнд гарсан эерэг үр дагавар ч хүн худалдаалах гэмт хэрэг үйлдэгдэхэд нөлөөлж байна.

Монгол Улсад үйлдэгдэн шийдвэрлэгдэж байгаа хүн худалдаалах гэмт хэргийн талаарх практикаас дараахь дүгнэлтийг хийж болохоор байна. Үүнд:

Нэгд, Нийгэмд гарч байгаа хүн худалдаалах гэмт хэргийг ихэвчлэн эрэгтэйчүүд үйлддэг гэсэн ойлголт үндэсгүй гэдэг нь харагдаж байна. Хүн худалдаалах гэмт хэрэгт сүүлийн таван жилд /2005-2010/ 16 хүн шийтгүүлснээс 7 буюу бараг 56 хувь нь эмэгтэй, биеэ үнэлэхэд бусдыг татан оролцуулах, биеэ үнэлэхийг зохион байгуулах гэмт хэрэгт 70 хүн шийтгүүлснээс 46 буюу 65.7 хувь нь эмэгтэйчүүд байжээ. Европын Холбооны орнуудад хүн худалдаалах гэмт хэрэгт шийтгүүлсэн эмэгтэйчүүдийн тоо бусад ихэнхи гэмт хэргийн тооноос илүүтэй байгаа ажээ.

Хоёрт, хүн худалдаалах гэмт хэрэг нь хохирогчид шууд хүч хэрэглэх буюу хүч хэрэглэхээр заналхийлэх аргаар бус, харин хуурч мэхлэх, залилах байдлаар үндсэндээ эхэлж үйлдэгдэж байгаа юм. Тухайлбал: хэргийн золиос болгож элсүүлэх, тээвэрлэх, хил нэвтрүүлэх ажиллагааны 90 гаруй хувь нь залилах, хууран мэхлэх замаар үйлдэгдсэн бол, харин хүлээн авагч оронд очсоны дараа хохирогчийн биеийг үнэлүүлэхдээ хүч хэрэглэх, хүч хэрэглэхээр заналхийлэх зэрэг аргыг хэрэглэдэг байна.

Гуравт, ял шийтгэгдсэн этгээдийн дийлэнх нь Монгол Улсын харъяат байна. Монгол иргэд гадаадын харъяат иргэдтэй /Хятад, Солонгос, Англи улсын харъяат/ хамтарч хүн худалдаалах гэмт хэргийг үйлдэн шийтгэгдсэн тохиолдол цөөн боловч гарчээ. Гэхдээ гадаадын иргэд оролцож үйлдэгдсэн хүн худалдаалах гэмт хэргийг шийдвэрлэх явцад нилээд хүндрэл учирдаг нь тэд хэрэг үүсгэх, шалгах, шийдвэрлэх явцад Монгол Улсын нутгаас гарч зугтах явдал гардагтай холбоотой юм.

Дөрөвт, гэмт хэргийн хохирогчид нь бүгд эмэгтэйчүүд байгаа бөгөөд энэ нь эрэгтэйчүүд хүн худалдаалах гэмт хэргийн хохирогч болохгүй гэсэн үг биш юм. 
Тавд, шүүн таслах практикт хүнийг зөвхөн бэлгийн мөлжлөгийн зорилгоор худалдаалагдсан хэрэг шийдвэрлэгдсэн байна. Хүүхэд худалдаасан болон хөдөлмөрийг мөлжих зорилгоор худалдсан асуудал шүүхээр шийдэгдээгүй байна. Хүн худалдаалах өөр нэг хэлбэр бол хөдөлмөрийн мөлжлөг мөн. Албадан хөдөлмөрлүүлэх нь бэлгийн мөлжлөгийг бодвол илрүүлэх, хор уршгийнх нь хэр хэмжээг тодорхойлоход хүндрэлтэй хэлбэр юм. Энэ нь боолын хөдөлмөр эрхлүүлэх, зарцлах, өрийн барьцаанд байлгах, хүүхэд, эхнэрийг барьцаалж мөнгө нэхэмжлэх, гуйлга гуйлгуулах зэрэг олон хэлбэртэй ажээ. Түүнчлэн хөдөлмөрийн гэрээ зөрчих, гурван “D” буюу Dangerous-амь насанд аюултай, Difficult-хүнд хүчир, Dirty-бохир заваан нөхцөлд ажиллахыг шаардах зэрэг болно.

Зургаад, хүний эд эрхтэнг авах болон “бие эрхтний мөлжлөг”-ийн /мансууруулах бодисын шууданч болгох, албадан гэрлүүлэх, хүүхэд тээлгэх гм/ зорилгоор үйлдэгдсэн хүн худалдаалах гэмт хэрэг Монгол Улсад одоогоор шийдвэрлэгдээгүй байгаа нь үүнээс урьдчилан сэргийлэх шаардлага байгааг харуулж байна.

Долоод, Монгол Улсын хувьд хүн худалдаалах гэмт хэрэгтэй холбоо бүхий асуудлуудыг цогцоор авч үзсэн тусгай хууль үгүйлэгдэж байна. Энэ гэмт үзэгдэлтэй зөвхөн эрүүгийн эрхзүйн арга хэрэгслээр тэмцэхэд учир дутагдалтай нь ажиглагдаж байна. Монгол Улс 2005 онд “Хүн худалдаалах, ялангуяа хүүхэд эмэгтэйчүүдийг бэлгийн мөлжлөгийн зорилгоор ашиглахаас хамгаалах хөтөлбөр батлан гаргасан боловч түүний хэрэгжилт, санхүүжилт, үр дүн тодорхой бус байгаа юм.

Наймд, бие үнэлэхтэй тэмцэх асуудал захиргааны аргаас хэтрэхгүй байна. Харин Үүнд өөр зохицуулалт шаардагдаж байна. Өөрөө биеэ үнэлэх нь эрүүгийн гэмт хэрэг биш гэж тооцдог учраас биеэ үнэлэхийг хүлээн зөвшөөрсөн улс орнууд байдаг. Гэхдээ гадаадын зарим улс орнуудад сайн дураараа биеэ үнэлэх, хүсэл зоригоос гадуур хүчээр биеийг нь үнэлүүлэх асуудлыг ялгаатай авч үзэж, зарим улс орнуудад биеэ үнэлэхийг хүлээн зөвшөөрч, биеийг нь хүчээр үнэлүүлэх, тэдний орлогоор мөнгө олох, биеэ үнэлэгчийг мөлжих, байр, сууц бэлдэхийг эргүүгийн гэмт хэрэгт тооцож ял шийтгэлттэй болгожээ.

Үүнээс үзэхэд Монгол Улсад хүн худалдаалах, бэлгийн мөлжлөгийн шинжтэй гэмт хэрэгтэй тэмцэх эрхзүйн орчин хараахан зохистой бүрдээгүй байна. Хүн худалдаалах, тэднийг бэлгийн мөлжөгт татан оролцуулах гэмт явдал гарахад ядуурал, ажилгүйдлийн өсөлт, үүнтэй холбоотой хүмүүс гадаадад шилжих хөдөлгөөн, гэр бүлийн хямрал, хүчирхийлэл, хууль тогтоомжийн цоорхой, боловсронгуй бус байдал зэрэг олон хүчин зүйл нөлөөлж байна. 


\section{Хар тамхи, мансууруулах бодисын хууль бус худалдаа (illegal drug trade), хэрэглээ, түүний илрэл}

Үндэсний болон олон улсын харилцаанд улс, үндэстэн дамнасан зохион байгуулалттай гэмт хэрэг, хүчирхийллийн өөр нэг шалтгаан нь хар тамхи, мансууруулах бодисын хууль бус худалдаа болж байна. НҮБ-ын 2005 оны илтгэлд дурдснаар мөн оны байдлаар дэлхийн ДНБ 36 их наяд ам. доллар байсан бол, хар тамхи, мансууруулах бодисын дэлхий нийтийн худалдааны өртөг 321.6 тэрбум ам. доллараар хэмжигдэж, хууль бус худалдаа нь глобаль худалдааны 1 хувиас давсан байна. АНУ жил тутам иргэдийн хар тамхи, мансууруулах бодис болон архи, дарсны зүй бус хэрэглээнээс болж 100 тэрбум ам. долларын хохирол амсаж байдаг ажээ. Тус улсад өдөрт 52 хүн мансууруулах бодисоос болж амиа алдаж, Канадын хүн амын нийт нас баралтын шалтгааны 21 хувийг эзэлж дэлхийд 200 сая гаруй хүн хар тамхи, мансууруулах бодис хэрэглэдэг гэсэн албан ёсны статистик тоо баримт гарчээ. Англид хууль бус мансууруулах бодис нь орон байрны хулгайн шалтгааны 50 хувийг эзэлдэг байна. Австрали улс жил тутам мансууруулах бодис хэрэглэгчдийн эмчилгээ, хууль сахиулалт болон ажлын бүтээмжийн алдагдалтай холбоотой зардалд 53 тэрбум австрали доллар зарцуулж байгаа ажээ. Байгаль орчинд учруулдаг хохиролыг арилгахад 1 грамм кокаин үйлдвэрлэхэд 4.4 метр кв. ширэнгэн ой устгадаг, ингэснээр жилд кокаины үйлдвэрлэлээс болж 300 мянган га ой мод үгүй болдог байна.

Монгол Улсын Өмнөд хөршид хар тамхи, мансууруулах бодис, сэтгэцэд нөлөөтэй эм бэлдмэлтэй холбоотой нөхцөл байдал тун хүндхэн байгаа билээ. 2009 онд БНХАУ-д хар тамхи, мансууруулах бодистой холбоотой хэрэгт 910 мянган хүн холбогдож, 770 мянган гэмт хэрэг бүртгэгдэн Бүх Хятадын Ардын Дээд Шүүхээс 510 мянган гэмт хэргийг шийдвэрлэж 560 мянган хүнийг гэмт хэрэгтэн гэж тооцон шүүхээс ял оноосон нь урьд оныхоос гэмт хэрэг 16,6 хувиар, хэрэг үйлдэгчдийн тоо 11,6 хувиар тус тус өсч, жилд 100,000 хүн хар тамхи, мансууруулах бодис хэрэглэсний улмаас амь насаа алдаж байгаа нь Хятадын анагаах ухааны судалгаагаар тогтоогджээ. Монгол Улстай хил залгаа ОХУ-ын Буриад улсад хар тамхи, мансууруулах бодис хэрэглэгчдийн тоо жилээс жилд өсч нас нь улам залуужиж байна. Буриадын мансууруулах бодистой тэмцэх албаны 2010 онд хийсэн мэдээллээс үзвэл тэдний ихэнх хувийг 18-30 насныхан эзэлж буй нь анхаарал татаж байгаа ба 2010 оны байдлаар Үлан-Үд хотын дунд сургуулийн 3000 сурагчдын 968 нь буюу 32 хувь нь наркологийн диспансерийн хяналтанд байдаг, Буриадын мансууруулах бодистой тэмцэх албаны хяналтанд 
мансууруулах бодис хэрэглэгч, дамлагч 6000 хүн бүртгэлтэй байгаа талаар мэдээлсэн юм.

Мансууруулах, сэтгэцэд нөлөөт эм бэлдмэл, бодисын хэрэглээ дэлхийн хэмжээнд хүн амын 18-аас дээш насныхан 8, 15-17 насныхан 18, 14 хүртэл насныхан 24 хувиар тус тус нэмэгдсэн ажээ.

Дэлхий нийтийг хамраад буй мансууруулах бодисын хууль бус эргэлттэй холбоотой асуудлууд Монгол Улсад тулгарч, сэтгэл түгшээсэн тоон үзүүлэлт жил ирэх тутам нэмэгдсээр байна. Мансууруулах, сэтгэцэд нөлөөт эм бэлдмэл, бодистой холбоотой 9 гэмт хэрэг 2008 онд бүртгэгдэж 19 хүн холбогдсон, 2009 онд 11 гэмт хэрэг бүртгэгдэж 39 холбогдсон, 2010 оны эхний 10 сарын байдлаар 15 гэмт хэрэг бүртгэгдэж 95 хүн холбогджээ. 1995-2010 оны 10 дугаар сарын байдлаар энэ төрлийн нийт 113 гэмт хэрэг дотоодод бүртгэгдэж 334 хүн холбогдсоноос 35 нь гадаад улсын иргэд байсан ажээ.

Түүгээр зогсохгүй Монгол Улсын иргэд Зүүн өмнөд Ази, Африк, Европ тивийг дамнасан хар тамхины гэмт бүлэглэлийн сүлжээнд холбогдож, БНХАУ, ОХУ зэрэг орнуудад Монгол Улсын иргэн хар тамхины тээвэрлэлт хийсэн гэмт хэрэгт хилийн чанадад шалгагдаж байна.

Монгол Улсын дотоод болон гадаад нөхцөл байдлаас үзэхэд хар тамхи, мансууруулах сэтгэцэд нөлөөтэй эм бэлдмэл, бодистой холбоотой нөхцөл байдал цаашид хүндэрч, тоон үзүүлэлт өсөх хандлага илт ажиглагдах болов. Гэтэл тус улсын ирээдүй болсон хүүхэд залуучуудын хэдэн хувь нь хар тамхи, мансууруулах, сэтгэцэд нөлөөт үйлчилгээтэй бодис хэрэглэгчдийн албан ёсны тоо гараагүй боловч хэд хэдэн төрлийн судалгаагаар Улаанбаатар, Эрдэнэт, Дархан, Замын-Үүд хотын өсвөр, дунд насныхны мансууруулах бодисын хэрэглээний байдалд хийсэн судалгаагаар жил ирэх тутам энэ төрлийн хэрэглээ өсч, тэд ихэвчлэн бензин, газ, гутлын тос, цавуу зэргийг хэрэглэж, дунджаар 17-20 насныхан мансууруулах, сэтгэцэд нөлөөтэй ургамал, эмийн бодисыг татаж мансуурч байгаа нь Нийслэлийн эрүүл мэндын газар, Нийслэлийн хүүхдийн төлөө газар, Хар тамхи, мансууруулах бодисоос иргэдийг хамгаалах нийгэмлэг ТББ, Мансууруулах бодисын эсрэг үндэсний төв ТББ-ын 2010 оны хамтарсан тандалт судалгаанаас ажиглагдаж байна 
Үүнийг шинжлэх ухааны үндэслэлтэй судалгааны аргачлалаар судлан тогтоох зайлшгүй чухал хэрэгцээ цаг үеэ дагаад урган гарч байгаa тул энэ төрлийн судалгааг төрийн болон ТББ-ын оролцоотой хийх шаардлагатай байна.

Монгол Улсын гадаад, дотоод орчин 20 жил ч биш бүр 10 жилийн өмнөхөөс ч эрс өөрчлөгдөж, эдийн засаг, мэдээлэл, харилцаа холбоо улам бүр даяаршлагдаж байгаа нь үндэсний аюулгүй байдал, ялангуяа хүний аюулгүй байдлын тогтолцоо, эрхзүйн орчныг боловсронгуй болгохыг зүй ёсоор шаардаж байгаа билээ.

\section{Ашигласан ном зүй}

1. Монгол Улсын Үндсэн хууль. УБ., 1992

2. Мянганы хөгжлийн зорилтод суурилсан үндэсний хөгжлийн цогц бодлого. УБ., 2008

3. Монгол Улсын үндэсний аюулгүй байдлын үзэл баримтлал. УБ., 2010

4. Монгол Улсын гадаад бодлогын үзэл баримтлал. УБ., 2011

5. Монгол Улсын Эрүүгийн хууль " УБ., 2002

6. Хүн худалдаалах гэмт хэрэг (эрхзүйн баримт бичгийн эмхтгэл) УБ., 2007

7. Гадаадын зарим улс орнуудын хүн худалдаалах гэмт хэрэгтэй тэмцэх хууль тогтоомжид хийсэн судалгаа. УБ.,2010

8. Гадаад харилцаа: (эрхзүйн баримт бичгийн эмхтгэл) УБ., 2004

9. Адьяабазар Д. "Мафи-гэмт байгууллага" УБ., 1999

10. Жанцан С. Төгс-Очир Ж. Монгол Улсын үндэсний болон хүн төрөлхтөний аюулгүй байдал, энхтайвны эсрэг гэмт хэрэгтэй явуулах эрүүгийн эрхзүйн тэмцэл УБ., 2007

11. Лхагвасүрэн О. Дэлхийн орнуудын далд эдийн засаг. УБ., 2008

12. Некрасов О.Ю. " Отмывание преступных доходов " М., 1999

13. Федеральный закон о противодействии легализаций доходов, полученных незаконным путем. 4 июля 1999 года. ДУМ, РФ

14. "Methods of Money Laundering” Business weekly USA., 2001. p. 5

15. Финансовой контроль над отмыванием криминальных доходов" www.omsker.ru/be[ryash/ch4j4.htm

16. "Контроль над бизнесом" http/antitax.ru/moshenik/book/ch4p.htm

17. Венская конвенция ООН о борьбе против незаконного оборота наркотических средств и психотропных веществ. М., 1988 